\title{
ATHEMATIC PARTICIPLES IN BRAZILIAN PORTUGUESE: A SYNCRETISM IN THE MAKING
}

\author{
PAULO CHAGAS DE SOUZA \\ Departamento de Lingüística - FFLCH \\ Universidade de São Paulo \\ Av. Prof. Luciano Gualberto, 403 \\ 05508-900 São Paulo \\ Brasil \\ pcsouza@usp.br
}

\begin{abstract}
Some Portuguese verbs have two different past participles, such as, e.g., aceitar 'accept', with participles aceitado and aceito; and limpar 'clean', with limpado and limpo. The first one in each pair mentioned is thematic, whereas the second one is athematic. While regular thematic participles all bear stress on the theme vowel, these athematic participles all bear the primary stress on the athematic stem. As the morphosyntactic category first person singular present indicative (1spi) is realized by $\{-0\}$, it normally coincides the masculine form of this athematic participle, giving rise to a syncretism between 1spi and the participle. The aim of this paper is to track the appearance of this kind of participle and the resulting syncretism in Portuguese and the changes making it possible for new participles to be formed in this way in colloquial Brazilian Portuguese.
\end{abstract}

Keywords: Brazilian Portuguese, verbs, paradigms, syncretism, rules of referral

\section{Introduction}

Portuguese has three verb conjugations, illustrated by examples such as amar 'love', querer 'want' and sentir 'feel'. The conjugations are reflected in the theme vowel of the infinitives: [a] for the first conjugation, [e] for the second, and [i] for the third. Practically all infinitives in Portuguese have a theme vowel, which then bears main stress. The only infinitive without a theme vowel (tv, henceforward) is the verb pôr 'put'. 
Past participles (henceforth, simply participles) are regularly formed on the thematic stem ${ }^{1}$ followed by the morpheme $\{-\mathrm{d}-\}$ and the gender morpheme. The plural morpheme may also be added at the end. The verbs mentioned in the first paragraph have, therefore, the following participles: amado, querido and sentido. ${ }^{2}$

This is not the only possible scheme for the formation of participles in Brazilian Portuguese (henceforth, BP). There are a considerable number of verbs which form participles without a theme vowel or the participle morpheme. While this may still be considered an irregular type, its number has been on the increase, particularly in colloquial spoken BP.

Let us first examine some verbs which may have two different participles, each following one of the schemes above. Those are verbs such as, e.g., aceitar 'accept', with participles aceitado and aceito; and limpar 'clean', with limpado and limpo. They are parsed below for clarity:

(1)

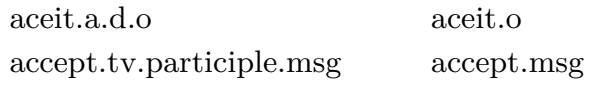

This is one of the two patterns of double participles in Portuguese. Note that the stem is the same in both forms of each verb. These will be referred to as Type-1 verbs with double participles. The other pattern is found with verbs from the second and third conjugations. This pattern shows consonant alternations normally inherited from Latin, such as prender 'to arrest', with participles prendido and preso, the latter regularly derived from the Latin participle prehensu-, and the former a regularized participle. These will be referred to as Type- 2 verbs with double participles.

Also note that while regular thematic participles all bear stress on the theme vowel, both of these kinds of athematic participles obviously cannot do so. Therefore, they all bear primary stress on the athematic stem.

As the morphosyntactic category first person singular present indicative (henceforth, $1 \mathrm{spi}$ ) is realized by $\{-\mathrm{o}-\}$, it normally coincides with the

${ }^{1}$ Note that the second conjugation theme vowel occurs as $\{-i-\}$ before the past participle morpheme $\{-\mathrm{d}-\}$.

${ }^{2}$ Participles will be cited in their masculine singular (msg) form. 
masculine form of this athematic participle, giving rise to a syncretism between 1spi and the participle in Type-1 verbs with double participles. This has been happening in spite of the fact that these two forms have no common morphosyntactic features whatsoever. Evidence not only for the existence of this syncretism with this group of verbs but also for the fact that speakers somehow relate the two forms is the growing extension of this pattern to other verbs.

The aim of this paper is to track the appearance of this kind of participle and the resulting syncretism in Portuguese, which is still in the process of taking place, as well as the changes making it possible for new participles to be formed in this way in colloquial BP. It is organized as follows: section $\mathbf{2}$ presents characteristics of Latin verbal paradigms which ultimately paved the way for the changes in Portuguese; section $\mathbf{3}$ details the changes that have taken place in Portuguese; and section 4 points to some further questions for future research. All through the paper, only internal factors will be taken into account. Throughout, the focus will be on Type- 1 verbs with double participles, which are the ones for which there has been the extension of a reanalyzed pattern.

\section{Latin}

The ultimate cause for the existence of such double participles in BP lies in properties of Latin conjugation and derivation, so it is best to start by examining its relevant properties. Table 1 shows the stems of the four Latin verb conjugations.

Table 1

Stems of regular verbs of the four Latin conjugations

\begin{tabular}{|c|c|c|c|c|}
\hline $\begin{array}{l}\text { Conjugation } \\
\text { (theme vowel) }\end{array}$ & Present Stem & Perfect Stem & Participle Stem & Meaning \\
\hline first $(\bar{a})$ & am-ā- & am- $\bar{a}-v-$ & am-ā-t- & 'love' \\
\hline second $(\overline{\mathrm{e}})$ & dēl-ēe- & dēl-ēev & dēl-ēet- & 'destroy' \\
\hline second $(\overline{\mathrm{e}})$ & hab-e-e- & hab-u- & hab-i-t- & 'have' \\
\hline fourth $(\overline{1})$ & aud-1-'- & aud-̄̄-v- & aud-̄̄-t- & 'hear' \\
\hline third $(\breve{\mathrm{e}})$ & leg-e- & leg- & lec-t- & 'read' \\
\hline third $(\breve{1})$ & cap-i- & cēp- & cap-t- & 'take' \\
\hline
\end{tabular}

Aronoff (1994) analyzes stems in Latin verbal morphology, building on the traditional analysis, according to which each verb normally has three 
stems: the present stem, the perfect stem and what he calls the third stem (more commonly named the participle stem, as in Table 1). The stems differ in meaning and in terms of what forms may be built on them, both inflectional and derivational forms.

The inflectional forms built on the third stem are the perfect participle, the future active participle and the supine. As an example, consider the forms of laudō 'praise':

(3) Present stem: laudā-

Perfect stem: laudā-v-

Third stem: laudā-t- $\left\{\begin{array}{l}\text { Perfect participle: laudātus, a, um } \\ \text { Future active participle: laudātūrus, a, um } \\ \text { Supine: laudātu(m) }\end{array}\right.$

Examining these forms, Aronoff concludes that there is no common semantic element present in all forms, not even if we limit ourselves to analyzing only inflectional forms. Considering its two most common uses, which are the two participles derived from the third stem, we see they have no common morphosyntactic feature, since one is a passive past participle and the other is an active future participle. In this way, the fact that these two participles are formed on the same stem is a morphomic, essentially arbitrary, fact, since there is no relation between them.

In derivational terms, it was possible to create new lexemes on the third stem, among which are the nomina agentis, with the suffix -or in the masculine singular and the nomina actionis, with the suffix -io in the nominative singular. Besides that, there was another morphomic property of Latin verbs, that is, the fact that it was possible to create verbs on the third stem. This is the other property which has reflexes in Portuguese grammar to this day and is also related to a great extent to the diachronic path of creation of athematic root-stressed participles in $\mathrm{BP}$.

According to Aronoff $(1994,46)$, there were three kinds of verbs derived on the third stem of Latin verbs: desideratives, iteratives and intensives.

Desideratives obviously denoted a wish, and were formed on the third stem by adding the ending -uriō, as in examples $\bar{e} s$-uriō 'want to

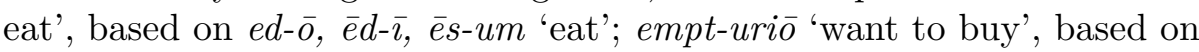
em- $\bar{o}, \bar{e} m-\bar{\imath}$, empt-um 'buy'; and part-urio 'want to give birth', based on pari- $\bar{o}$, peper- $\bar{\imath}$, part-um 'give birth'. This kind of verb formation process was lost in the Romance languages. 
Iteratives denoted repetition and were formed by adding the ending -itō-itāre to the athematic form of the third stem, as in examples

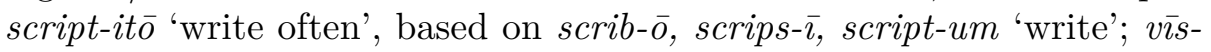

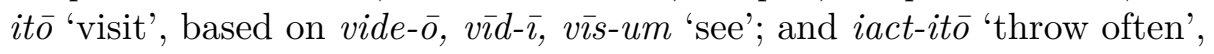
based on iaci-o, ie $\bar{e} c-\bar{\imath}$, iact-um 'throw'.

Intensives, on the other hand, were formed simply by adding first conjugation endings, including the theme vowel $-\bar{a}$ - to the athematic form of the third stem. This is how verbs such as the following were formed:

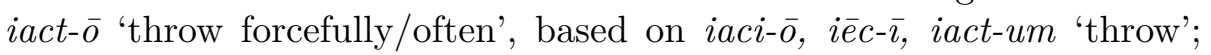

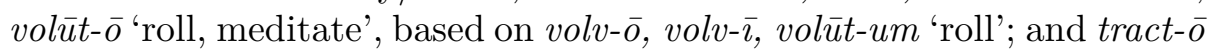
'drag, handle', based on trah-ō, trax- $\bar{\imath}$, tract-um 'pull'.

Although there may have been a semantic difference between iteratives and intensives, it was apparently eliminated, both having converged in meaning in many cases. There was semantic bleaching of this kind of intensive verbs, a repeatedly mentioned characteristic of the process of grammaticalization. What were initially two verb formation processes associated with different meanings became simply two possible mechanisms for word-formation.

Allen and Greenough $(1888,159)$ state in this regard: "Intensives or iteratives are formed from the Supine stem and end in -tō or -itō (rarely -sō). They denote a forcible or repeated action, but this special sense often disappears."

Ernout and Meillet (1967 [1932]) make similar remarks: "à canō correspond un intensif cantō, $\bar{a} s$, $\bar{a} u \bar{\imath}, \bar{a} t u m, \bar{a} r e$, qui, dès les plus anciens textes, concurrence canō sans que la nuance itérative ou intensive soit toujours visible."

They also say that based on $i a c i \bar{o}$ the frequentative $i a c t \bar{o}, \bar{a} s$, 'lancer, jeter souvent ou avec force', was formed, and that it later started to mean 'agiter' or 'mettre en avant'. They conclude by saying that "Iactare [...] qui à basse époque s'emploie comme synonyme de iaciō, a seul subsisté et a remplacé iacere dans les langues romanes."

One further remark they make is that "de saliō existe un itératifintensiv ancien et usuel saltō, $\bar{a} s[\ldots]$ qui tend à se substituer à salīre."

The formation of intensive verbs is the one that matters for our purposes here. It is important to bear in mind that this kind of derived (intensive) verbs always belonged to the first conjugation. What Aronoff calls the morphomic level contains purely morphological properties. In this sense, it is a morphomic fact that the third stem of Latin verbs is 
ultimately the base on which both the past participle and the so-called intensive verbs are formed. Some more examples follow:

(4) crepo, crepare, crepitum 'rattle, crack'

crepito, crepitare, crepitatum 'crack repeatedly'

(5) verto, vertere, versum 'turn'

verso, versare, versatum 'whirl'

(6) cedo, cedere, cessum 'grant, give'

cesso, cessare, cessatum 'cease'

(7) pello, pellere, pulsum 'hit, drive away'

pulso, pulsare, pulsatum 'knock, strike (the hour)'

As a result of the creation of these new verbs, Latin had some participles related to two lexemes at the same time. The stem puls- found in the participle pulsum contained the third stem of the primitive verb pello and was identical to the bare stem of the derived verb pulso.

Sometimes, derivatives ended up 'leading a life of their own', undergoing an independent semantic drift:

(8) habeo, habere, habitum 'have, occupy' habito, habitare, habitatum 'inhabit'

Anyway, we should note that the past participle eventually became lexically related to two different lexemes, since habitum, e.g., was related both to habeo and to habito.

\section{Portuguese}

Portuguese preserved several irregular Latin participles, but in many cases they were gradually regularized. Older participles sometimes survived as nouns, adjectives or as double participles. E.g.:
(9) as N:
defender 'defend'
defendido
defeso
(> defesa 'defense')
(10) as A:
possuir 'possess'
possuído
possesso
(> 'very angry')
(11) doublet:
imprimir 'press'
imprimido
impresso 
The two most frequent groups of Portuguese verbs with double participles originated in Latin irregular forms which were regularized. This could happen to verbs in all conjugations. The examples above show verbs from the second and third conjugation. Note that in those cases no new verb was created, either in Latin or in Portuguese. What happened to several first conjugation verbs, however, was that a new verb was created. As participles may lead a somewhat independent life from the verb they are related to, while often both participle and verb were preserved, it was sometimes the case that only one of them was maintained, the other being lost. This can be seen in a few verbs derived from Latin capio 'take', namely recipio, accipio and percipio. We have in example (12) a present tense form, followed by its corresponding participle and another verb derived from it.
(12) recipio receptum recepto
accipio acceptum accepto
percipio perceptum

The verbs recepto and accepto were formed in Latin itself. There was no verb percepto in common use. The verb recipio remained in use, but its participle was regularized in Portuguese, receito having been replaced by recebido. There is still the noun receita 'recipe' based on this disused participle. The verb accipio had the participle acceptum, on which the verb accepto was formed. Between Latin and Portuguese, the verb accipio fell into disuse, but its participle acceptum/aceito remained in use, as well as the derived verb accepto, which yielded Portuguese aceitar, on which a regular participle was formed, aceitado. The result was that aceitar now had two participles, one inherited from Latin, aceito, and one created in Portuguese, aceitado. ${ }^{3}$

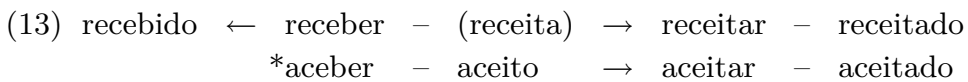

The diagram above shows the Portuguese correspondents of those two Latin verbs. The inflectional links are shown by means of a dash. The infinitive forms of Portuguese verbs originally existing in Latin appear

${ }^{3}$ There are differences in usage between them. The Latinate participle predominates in passive constructions, being sometimes the only possibility, whereas the regularized participle is sometimes more common in perfective tenses. This difference, however, is orthogonal to the discussion here. 
in the second column. The starred verb ${ }^{*}$ aceber does not exist in Portuguese. The first column contains participles regularized in Portuguese. The third column contains Portuguese forms of the past participles of the verbs as they would develop from Latin. The fourth column contains verbs derived from those participles, followed in the last column by their regular participles.

What has been changing recently is that the opposite process of formation of new participles has been taking place, i.e., verbs having thematic participles have had athematic participles coming into use. In addition, this formation of athematic participles has been gradually extended to other verbs in colloquial speech, as follows:

(14) 1st phase: only doublets resulting from Latin participles. Circumscribed to verb roots ending in alveolar obstruents (mostly $t$, but also $s, d$ ), e.g.,

(a) aceitar 'accept': aceitado/aceito (< acceptu-)

Eu tinha aceitado/aceito a oferta.

'I had accepted the offer.'

(b) expulsar 'expel, kick out': expulsado/expulso ( $<$ expulsu-)

O professor tinha expulsado/expulso o aluno.

'The teacher had expelled the student.'

(c) findar 'finish': findado/findo ( $<$ finitu-) (uncommon in current BP)

(15) 2nd phase: the beginning of the extension to other 1st conjugation verbs. Note that originally only thematic participles existed. Athematic participles were created analogically, e.g.,

(a) pagar 'pay': pagado/pago (a few found in standard BP)

Eu tinha pagado/pago a conta.

'I had paid the bill.'

(b) chegar 'arrive': chegado/chego (and several others not found in standard BP)

A carta tinha chegado/chego.

'The letter had arrived.'

(16) 3rd phase: the process of creation of athematic participles is being extended to verbs in other conjugations (also not found in standard BP), e.g.,

(a) trazer 'bring': trazido/trago

O professor tinha trazido/trago o livro.

'The teacher had brought the book.'

(b) pedir 'request': pedido/peço

O presidente tinha pedido/peço paciência.

'The president had asked for patience.' 
Apparently, this kind of participle (phases 2 and 3 ) is a unique innovation among Romance languages. Note that the restriction of the creation of a second participle in phase 2 to first conjugation verbs is a result of the fact that intensives/iteratives in Latin produced first conjugation verbs. So, although phase 2 shows the reinterpretation and extension of a pattern, the result of this extension is still within the diachronically conditioned boundaries. Phase 3, which is still in its inception, shows speakers have detached themselves of this restriction to first conjugation verbs, since verbs in the other conjugations have also begun to show this kind of participle. Finally, one should note that the active "mirroring" of the 1psi is more transparent in verbs with morphophonemic alternations restricted to that form and to the present subjunctive, regularly formed on the same stem (cf. phase 3). An originally accidental pattern - a morphomic fact relating inflection and derivation - has been reinterpreted as systematic, as Baerman $(2005,810)$ argues may happen.

\section{Final remarks}

At least descriptively, the process may be captured by a directional rule of referral (Zwicky 1985; Stump 1993) stating that the singular masculine form of the participle (its default form, used e.g., in perfect tenses) coincides in form with the 1 psi. Although some frameworks reject the use of rules of referral, it seems very unlikely that the process could be described by means of underspecification or the like, mainly because the two slots in the verb paradigm do not form a natural class at all. Even Wunderlich (2003), which questions the use of rules of referral, seems to accept their interpretation as tools to capture diachronic generalizations. The best way to account for these changes that have been taking place in $\mathrm{BP}$ verbal morphology within a theoretical framework will be the subject of future research.

\section{References}

Allen, Joseph Henry - James Bradstreet Greenough 1888. New Latin grammar. Ginn and Company, Boston.

Aronoff, Mark 1994. Morphology by itself. Stems and inflectional classes. MIT Press, Cambridge MA.

Baerman, Matthew 2005. Directionality and (un)natural classes in syncretism. In: Language $80: 807-27$. 
Ernout, Alfred - Antoine Meillet 1967 [1932]. Dictionnaire étymologique de la langue latine: Histoire des mots. Klincksieck, Paris.

Stump, Gregory T. 1993. On rules of referral. In: Language 69:449-79.

Wunderlich, Dieter 2003. Is there any need for the concept of directional syncretism? In: Lutz Gunkel - Gereon Müller - Gisela Zifonun (eds): Explorations in nominal inflection, 373-95. Mouton de Gruyter, Berlin \& New York.

Zwicky, Arnold M. 1985. How to describe inflection. In: Proceedings of the Berkeley Linguistics Society $11: 372-86$. 